\title{
Targeting Peroxisome Proliferator Activated Receptor $\alpha$ (PPAR $\alpha$ ) for the Prevention of Mitochondrial Impairment and Hypertrophy in Cardiomyocytes
}

\author{
Dipak Kar Arun Bandyopadhyay \\ Cell Biology and Physiology Division, CSIR - Indian Institute of Chemical Biology, Kolkata, India
}

\author{
Key Words \\ Cardiomyocyte $\cdot$ Mitochondria $\bullet$ Fenofibrate $\cdot$ PPAR $\alpha \cdot$ Hypertrophy
}

\begin{abstract}
Background/Aims: Morphological and biochemical maladaptation of cardiomyocytes are associated with mitochondrial dysfunction and dysregulation in hypertrophic conditions. Peroxisome proliferator activated receptor $\alpha$ (PPAR $\alpha)$, a drug target for dyslipidemia, is known to be downregulated in cardiomyocytes in response to hypertrophic stimuli. The current study was undertaken to investigate the role of PPAR $\alpha$ signaling in mitochondrial remodeling and thereby dysregulation of cardiomyocytes due to hypertrophy in vitro. Methods: Rat cardiomyocytes H9c2 (2-1) and neonatal rat ventricular myocytes (NRVMs) were cultured and treated with $\alpha_{1}$-adrenergic agonist phenylephrine (PE, $100 \mu \mathrm{M}, 24$ hours) in the presence or absence of $10 \mu \mathrm{M}$ fenofibrate or bezafibrate. Cellular hypertrophy was observed by atomic force microscopy and immunofluorescence with F-actin antibody. mRNA levels of hypertrophic marker genes and other genes were examined by quantitative real time PCR. Structural as well as functional remodeling of the mitochondria were evaluated by immunofluorescence ( $F$-actin and COX-I), live cell imaging microscopy (JC-I, mitotracker), mitochondrial complex $\mathrm{V}$ activity, MPTP activity and ATP assay. Oxidative stress was measured by using sensitive fluorescent indicator probes. Cellular and mitochondrial calcium were measured by using fluorescent indicator probes Rhod-2 AM and X-rhod-1 AM, respectively. Targetscan prediction analysis was performed to find out miRNAs as putative regulators of VDAC. Luciferase assay was conducted to confirm binding of miR28 with VDAC. Results: Co-treatment of H9c2(2-1) cells with $P E$ and fenofibrate restricted increase in cell size and expression of marker genes such as atrial-natriuretic peptide (ANP), brain-natriuretic peptide (BNP) and $\beta$-myosin heavy chain $(\beta-\mathrm{MHC})$ compared to those with $\mathrm{PE}$ alone. Fenofibrate prevented $\mathrm{PE}$-induced down regulation of PPAR $\alpha$-target genes like CPT-I and MCAD. Mitochondrial trans-membrane potential $\left(\Delta \psi_{\mathrm{m}}\right)$ and motility were reduced by PE which were significantly checked by fenofibrate. Increased ROS production and calcium level in PE-treated cells were ameliorated by fenofibrate. Mitochondrial
\end{abstract}




\section{Cellular Physiology Cell Physiol Biochem 2018;49:245-259 \\ \begin{tabular}{ll|l} 
DOI: 10.1159/000492875 & $\begin{array}{l}\text { O 2018 The Author(s). Published by S. Karger AG, Basel } \\
\text { www.karger.com/cpb }\end{array}$
\end{tabular} \\ Kar et al.: Role of PPAR $\alpha$ in Prevention of Cardiomyocyte Hypertrophy}

activity and ATP generation were reduced by PE which was rescued by fenofibrate. Fenofibrate also prevented PE-induced down regulation of mitochondrial genes like VDAC-I and COX-IV. Expression of several miRNAs was altered in hypertrophic cardiomyocytes which were restored when co-treated with fenofibrate. miR28 was found to target 3 'untranslated region of VDAC-I. Conclusion: Overall, the results demonstrate that PPAR $\alpha$ signaling is critically involved in mitochondrial dysfunction in hypertrophic cardiomyocytes in which miR28 plays a pivotal role.

(C) 2018 The Author(s)

Published by S. Karger AG, Basel

\section{Introduction}

In living organisms, highly efficient cellular adaptive mechanisms to external stimuli provide enormous biochemical plasticity which allows normal physiological process to continue up to a certain limit. When the limit of such biochemical plasticity is reached, a pathological situation is shaped which might be initiated at the molecular level and ultimately summed up in the form of disease phenotypes. In the cardiovascular system, pathological conditions such as hypertension, ischemia, valve disease etc. induce myocyte hypertrophy which is characterized by increase in cell size accompanied by transcriptional and bioenergetic remodeling. Cardiomyocyte hypertrophy is an excellent example of adaptive changes which ultimately transform into maladaptive stage in the event of chronic stress [1-3]. The external mechanical stress to the cardiomyocytes which influences biochemical signaling eventually may jeopardize intracellular organelles. In cardiomyocytes, the mitochondrion is one of such targets of chronic stress in which bioenergetic imbalance and dysfunction are very prominent [4-6]. Mitochondria form highly interconnected and dynamic network in cardiomyocytes and provide necessary ATPs for smooth functioning of the heart [5]. Normal adult heart acts as an efficient pump thereby using huge amount of ATP throughout its life cycle. Under normal circumstances majority of ATP is generated through fatty acid and glucose oxidation inside mitochondria [7]. Therefore, proper mitochondrial functional machinery is essential for smooth functioning of the cardiomyocytes $[6,8]$.

In adult heart muscles, fatty acid $\beta$-oxidation provides approx. $60-90 \%$ of the total energy whereas rest of the energy is supplied by glucose oxidation $[9,10]$. Interestingly, heart can change the relative involvement of the substrates in an effort to adjust to varying physiological conditions [11]. In hypertrophic cardiomyocytes, steady supply of energy is hindered due to break down of mitochondrial machinery which may ultimately lead to cardiac failure $[12,13]$. Peroxisome proliferator activated receptors (PPARs) which belong to the nuclear receptor super family play a significant role in cardiac energetics and cardiac metabolism [14]. Although all three PPARs play essential roles in fatty acid metabolism, PPAR $\alpha$ is the principle transcription factor in tissues with high fatty acid oxidation rates e.g. heart, skeletal muscle, liver, kidney etc. and play important role in cardiac energetics $[15,16]$. Like other nuclear receptors, PPAR $\alpha$ has a ligand independent transcriptional activation domain (A/B or AF-I), C domain or DNA binding domain (DBD), D domain and ligand binding domain (LBD) including ligand dependent activation domain (E/F or AF-II). PPAR $\alpha$ forms obligate heterodimers with 9-cis retinoic acid receptor (RXR). This activated heterodimer enters the nucleus and binds to specific DNA sites composed of direct repeat of six nucleotides of AGGTCA separated by one or two base pairs which are located at the promoter or enhancer site of PPAR $\alpha$ target genes including fatty acid $\beta$ oxidation genes [17, 18]. Several synthetic ligands are available in the market which can act as PPAR activators e.g. fibrates like bezafibrate, fenofibrate, clofibrate etc. can activate PPAR $\alpha$ whereas TZDs (e.g. rosiglitazone, pioglitazone etc.) can activate PPAR $\gamma[18]$. Several important genes in fatty acid oxidation are downregulated and expression of PPARs like PPAR $\alpha$ are also reduced during cardiac hypertrophy [19]. Previously, we have also shown that PPAR $\alpha$ agonist bezafibrate inhibited thyroid hormone induced cardiac hypertrophy via prevention of mitochondrial dysfunction suggesting cardioprotective function of the fibrates [20]. Recently, we have also reported that the dynamic state is very important for maintaining the functional state of mitochondria by using single cell fluorescence microscopy in H9c2 cardiomyocytes [21]. 


\section{Cellular Physiology Cell Physiol Biochem 2018;49:245-259 \begin{tabular}{l|l|l} 
and Biochemistry Published online: 23 August, 2018 & $\begin{array}{l}\text { @ } 2018 \text { The Author(s). Published by S. Karger AG, Basel } \\
\text { www.karger.com/cpb }\end{array}$ \\
\hline
\end{tabular}}

Growing evidences suggest that microRNAs (miRNAs) are important mediators of cellular signaling and play crucial roles in cardiac hypertrophy and heart failure [22, 23]. miRNAs are highly conserved class of small non coding single stranded RNAs with approximate length of 18-25 nucleotides. They bind to 3' untranslated region (UTR) of their target messenger RNAs (mRNAs) by base pairing and act as key regulators of gene expression [24]. Several miRNAs are shown to be critically involved in cardiac hypertrophy, however few information are available in PPAR $\alpha$ signaling and mitochondrial dysfunction in hypertrophy of the cardiomyocytes.

Although PPAR $\alpha$ signaling is known to be associated with hypertrophic growth of cardiomyocytes, the molecular mechanism of mitochondrial impairment via this pathway in hypertrophy remains unknown. In this study, we investigated the mechanism of mitochondrial dysfunction in cardiomyocytes in the background of $\alpha_{1}$-adrenergic stimulation by phenylephrine and examined the causative role of PPAR $\alpha$ signaling in the downstream effect. The results demonstrated a novel mechanism by which physical and physiological states of mitochondria are altered involving miRNA28 in PPAR $\alpha$ signaling pathway. Thus, PPAR $\alpha$ plays a unique role in nuclear-mitochondrial cross talk signifying mitoprotection by its agonists in hypertrophied cardiomyocytes.

\section{Materials and Methods}

\section{Cell culture, transfection, drug treatments}

Rat cardiomyocyte cell line H9c2 (2-1) used in this study was obtained from the cell repository of NCCS (Pune, India). Cells were cultured in DMEM, supplemented with 10\% FBS, Penicillin-streptomycin. Cells were maintained at $37^{\circ} \mathrm{C}$ in humid conditions with $5 \% \mathrm{CO}_{2}$. Different DNA constructs were transfected using transfection reagent (Qiagen) in the presence or absence of miRNA mimics or miRNA inhibitors. Phenylephrine (PE from Sigma) dissolved in sterile water, bezafibrate and fenofibrate (from Sigma) dissolved in di-methyl sulfoxide (DMSO) were used for treatment in cell culture. Several earlier studies showed that $100 \mu \mathrm{M}$ PE in 24 hours caused hypertrophy of cardiomyocytes in vitro [21, 25-27]. Therefore, in the present study, hypertrophy in H9c2 cardiomyocytes was induced by treatment with $100 \mu \mathrm{M} \mathrm{PE}$ for 24 hours. The H9c2 cardiomyocytes were also treated either with $10 \mu \mathrm{M}$ fenofibrate or $10 \mu \mathrm{M}$ bezafibrate in the absence or presence of PE $(100 \mu \mathrm{M})$. This dose $(10 \mu \mathrm{M})$ of fenofibrate or bezafibrate for activating PPAR $\alpha$ was selected based on earlier studies [28, 29]. In case of co-treatment, cells were pre-treated with $10 \mu \mathrm{M}$ fenofibrate or bezafibrate 1 hour before PE treatment.

\section{Monitoring cellular hypertrophy by Atomic Force Microscopy (AFM)}

The spatial increase in cell size was analyzed by AFM of fixed cells as reported earlier with minor modifications [25]. Briefly, H9c2 cardiomyocytes were pretreated with or without $10 \mu \mathrm{M}$ fenofibrate and incubated in the presence of $100 \mu \mathrm{M}$ PE for 24 hours. Post treatment, cells were washed 5 times with $1 \mathrm{X}$ PBS (filtered through $0.22 \mu \mathrm{m}$ filter). Cells were then fixed with $3.7 \%$ paraformaldehyde (PFA) solution for 20 minutes in dark followed by washing three times with $1 \mathrm{X}$ PBS. Scanning of cell surface was carried out in contact mode using Agilent (La Jolla, CA, USA) 5500-ILM AFM with a piezo-scanner (maximum range: 100 $\mu \mathrm{m})$.

\section{Isolation of neonatal rat ventricular myocyte (NRVM)}

Neonatal Rat Ventricular Myocytes (NRVM) were isolated from 2-3 day old Sprague dawley rat pups as reported earlier [21, 30,31]. Experiments involving animals were approved by the Institutional Animals Ethics Committee (IAEC). The animals were handled as per the guidelines of the IAEC in accordance with the committee for the purpose of Control and Supervision of Experiments on Animals (CPCSEA), Ministry of Social Justice, Govt. of India. In brief, hearts were removed, squeezed and rinsed with $1 \mathrm{X}$ Ads buffer ( $\mathrm{NaCl}$ 116.3mM, HEPES 19.7mM, $\mathrm{NaH}_{2} \mathrm{PO}_{4} 9.4 \mathrm{mM}$, glucose $5.5 \mathrm{mM}, \mathrm{KCl} 5.3 \mathrm{mM}, \mathrm{MgSO}_{4} 0.83 \mathrm{mM}$ and 100 units/ $\mathrm{ml}$ penicillin/streptomycin, $\mathrm{pH}$ 7.4) to remove blood. Atria were removed and ventricles were cut into small pieces and minced with scissors and incubated at $37^{\circ} \mathrm{C}$ in enzyme solution $[0.2 \%$ collagenase type II $\left(270\right.$ units $/ \mathrm{mg}$ ), pancreatin $(0.6 \mathrm{mg} / \mathrm{ml})$ in $1 \mathrm{X}$ Ads buffer] in presence of $95 \% \mathrm{O}_{2}, 5 \% \mathrm{CO}_{2}$ for 4 successive 


\section{Cellular Physiology Cell Physiol Biochem 2018;49:245-259 \begin{tabular}{l|l|l} 
and Biochemistry & Published online: 23 August, 2018 & $\begin{array}{l}\text { C } 2018 \text { The Author(s). Published by S. Karger AG, Basel } \\
\text { www.karger.com/cpb }\end{array}$ \\
\hline
\end{tabular}}

Kar et al.: Role of PPAR $\alpha$ in Prevention of Cardiomyocyte Hypertrophy

digestions with 10 mins each. The supernatants of the first tissue digest were discarded. Supernatants obtained after each $10 \mathrm{~min}$ digestion period were centrifuged for $10 \mathrm{~min}$ at $1000 \mathrm{~g}$. Cell pellets obtained at each round of digestion were re-suspended in 3ml of complete M199 (medium 199 supplemented with $10 \%$ fetal bovine serum, $2 \mathrm{mM}$ L-glutamine and $100 \mathrm{U} / \mathrm{ml}$ penicillin-streptomycin, $\mathrm{pH}$ 7.15) before filter sterilization through a $0.22 \mu \mathrm{m}$ filter. Entire cell pellets were pooled and pre-plated in flask and incubated for 1 hour in a $\mathrm{CO}_{2}$ incubator [5\% v/v], humidified atmosphere and $37{ }^{\circ} \mathrm{C}$ to enrich cardiomyocytes. The resultant unattached cardiomyocyte suspension was centrifuged and the resultant pellet resuspended in complete M199 followed by plating onto collagen I-coated cover glasses (BIOCOAT, BD Labware, Bedford, USA) and incubated in a $\mathrm{CO}_{2}$ incubator. Fresh, complete M199 was replaced after $24 \mathrm{~h}$ with serum free M199. Majority of the cells were cardiomyocytes as they continued beating spontaneously after one day or more. Cardiomyocytes were also validated by immunostaining with cardiac specific anti- $\alpha$ actinin antibody (Sigma).

\section{RNA isolation and quantitative real time PCR}

Total RNA was extracted using RNeasy mini kit (Qiagen) according to manufacturer's instructions. For each sample $2 \mu \mathrm{g}$ of mRNA was reverse transcribed into cDNA using Revert Aid First Strand cDNA synthesis kit (Thermo Scientific, Glen Burnie, Maryland, USA). cDNA was then subsequently used for quantitative real time PCR using Dynamo SYBR Green qPCR kit (Finnzyme, Waltham, MA, USA) on 7500 fast real time PCR system (Applied Biosystems, Foster city, CA, USA). 18S rRNA was used as normalizing control or internal reference. All reactions were performed in a total reaction volume of $20 \mu$ l. Fold changes in mRNA levels of the respective genes have been calculated from $C_{T}$ values using $2^{-\Delta \Delta C}$ method [32]. Primer 3 software (http://bioinfo.ut.ee/primer3-0.4.0/) was used to design sequence specific PCR primers as indicated in Table 1.

ATP assay

ATP concentration was measured from $\mathrm{H} 9 \mathrm{c} 2$ cardiomyocytes using ATP colorimetric/fluorometric assay kit from BioVision, Mountain view, CA, USA as per manufacturer's protocol. Briefly, The H9c2 cardiomyocytes were pretreated with or without $10 \mu \mathrm{M}$ fenofibrate and incubated in the presence of 100 $\mu \mathrm{M}$ PE for 24 hours. Cell pellet from different treatment groups were dissolved in $100 \mu \mathrm{l}$ of ATP assay buffer provided in the assay kit. Following ice cold centrifugation at $15000 \mathrm{~g}$ for 2 minutes, supernatant was collected from each sample and ATP concentration was measured using ATP colorimetric/fluorometric assay kit from BioVision as per manufacturer's protocol.

\section{Mitochondrial complex V (ATP Synthase) activity assay}

Mitochondrial complex V (ATP Synthase) activity was determined by checking the activity of ATP Synthase enzyme from Novagen. ATP synthase is immunocaptured within the wells. The enzyme functions by hydrolyzing ATP to ADP and phosphate. Production of ADP is ultimately coupled to the oxidation of $\mathrm{NADH}$ to $\mathrm{NAD}^{+}$which is monitored as a decrease in absorbance at $340 \mathrm{~nm}$. Briefly, H9c2 cardiomyocytes were pretreated with or without $10 \mu \mathrm{M}$ fenofibrate and incubated in the presence of $100 \mu \mathrm{M}$ PE for 24 hours. Cell pellet from different treatment groups were dissolved in $200 \mu \mathrm{l} 1 \mathrm{X}$ DPBS followed by snap freezing and thawing. After centrifugation at $12000 \mathrm{~g}$, the sample was resuspended in a solution provided in the kit. The resuspended sample was further processed and mitochondrial complex $\mathrm{V}$ activity was measured using the Novagen assay kit as per manufacturer's protocol.

Table 1. List of primers used in quantitative real time PCR

\begin{tabular}{lcc}
\hline Name of oligos & Forward (5'-3') & Reverse (5' $\left.{ }^{\prime} 3^{\prime}\right)$ \\
\hline ANP & GTGTCCAACACAGATCTGATGG & GCCAGCGAGCAGAGCCCTCA \\
BNP & TGGGAAGTCCTAGCCAGTCTC & GCCGATCCGGTCTATCTTCTG \\
$\beta$-MHC & CGCTCAGTCATGGCGGAT & GCCCCAAATGCAGCCAT \\
PPAR $\alpha$ & CCTGTCCGTCGGGATGTCACAC & GTGACGGTCTCCACGGACATGC \\
CPT-I & GCTACACGGAGACAGGACACTG & TGCCTTTGTCCCGGAAATGAGC \\
MCAD & ATGGGTCAGCGGTGCTCTGA & TGAAACTCCTTGGTGCTCCACTAG \\
VDAC & CAACACGGAGACCACCAAAG & TCATAGCCAAGCACCAGAGC \\
COX-IV & TGAAGACTATGCTCTCCCGTCT & ACGTAGCTCTTCTCCCAGATCA \\
18S rRNA & CGGCTACCACATCCAAGGAA & AGCTGGAATTACCGCGGC
\end{tabular}




\section{Cellular Physiology Cell Physiol Biochem 2018;49:245-259 \begin{tabular}{l|l|l} 
and Biochemistry Published online: 23 August, 2018 & $\begin{array}{l}\text { (c) } 2018 \text { The Author(s). Published by S. Karger AG, Basel } \\
\text { www.karger.com/cpb }\end{array}$
\end{tabular}}

\section{Immunofluorescence and live cell imaging microscopy}

Cells were cultured in $35 \mathrm{~mm}$ glass bottom dishes (MatTek, Ashland, MA, USA), pretreated with or without $10 \mu \mathrm{M}$ fenofibrate and incubated in the presence of $100 \mu \mathrm{M}$ PE. After 24 hours, cells were processed either for immunofluorescence (COX-I and F-actin) or live cell imaging for monitoring various mitochondrial parameters such as membrane potential, mitochondrial permeability transition pore (MPTP) activity, dynamicity, oxidative stress and calcium homeostasis. For immunofluorescence, cells were fixed with $3.7 \%$ paraformaldehyde for 15 minutes and permeabilized using $0.2 \%$ Triton X-100 for 10 minutes. Cells were blocked with $1 \%$ BSA solution for 30 minutes at room temperature and then incubated with anti-COX-I monoclonal antibody (Invitrogen, Carlsbad, CA, USA) followed by Alexa Fluor 488 goat anti-rabbit secondary antibody (Molecular Probes, Inc.). F-actin staining was performed with Alexa Fluor 532 Phalloidin as per manufacturer's instructions. Mitochondrial membrane potential was measured by JC-1 membrane potential assay kit (Cayman Chemicals, Ann Arbor, MI, USA). Image-iT live mitochondrial transition pore assay kit (Molecular Probes, Inc.) was utilized for monitoring MPTP. Cellular and mitochondrial oxidative stress were measured by using CellROX Deep Red Reagent and MitoSOX Red mitochondrial superoxide indicator (Molecular Probes Inc., USA), respectively. Cellular and mitochondrial calcium were measured by using Rhod-2 AM and X-rhod-1 AM, respectively (Molecular Probes, Inc.). All these assays were performed as per the manufacturers' instructions. Confocal imaging was performed using TCS-SP2 confocal point scanner (Leica Microsystems, Mannheim, Germany) and spinning disc confocal microscope (Andor Technology, Belfast, UK) equipped with Olympus IX81 microscope, Yokogawa CSU-X1 spinning disc and iXon 897 EMCCD camera. Movies on mitochondrial dynamics were recorded using spinning disc confocal microscope system and 60X/1.42 NA oil-immersion objective was used for image acquisition via AndoriQ 2.7 software.

\section{Luciferase assay}

pSiCheck2 dual luciferase reporter plasmid vector containing 3' UTR of VDAC-I (614bp) was obtained as a kind gift from Dr. Beena Pillai, CSIR-IGIB (New Delhi, India). Transfections were performed using transfection reagent (Qiagen) according to manufacturer's instructions. For luciferase activity dual reporter luciferase assay kit (Promega) was used. The dual-luciferase reporter assay system provides an efficient means of performing two reporter assays. In the DLR assay, the activities of firefly (Photinus pyralis) and Renilla (Renillareniformis or sea pansy) luciferases were measured sequentially from a single sample. Firefly luciferase reporter was measured first by LAR II to generate a luminescent signal which lasted for appx. 1 $\min$. After measuring firefly luminescence, the reaction was quenched and the renilla luciferase reaction was initiated simultaneously by adding stop \& glow reagent to the sample. Unless otherwise mentioned, $300 \mathrm{ng}$ of luciferase reporter plasmid vector and $20 \mathrm{nM}$ of miRNA mimic were applied. 72 hours post transfection, cultured transfected cells were rinsed in kit provided 1X PBS. Following removal of all rinse solutions, cells were lysed passively by kit provided 1 X PLB by gently rocking for 15 minutes at room temperature. Luciferase activity was measured using kit provided LAR II reagent and stop\& glow reagent according to manufacturer's instructions.

\section{MPTP activity}

Mitochondrial Permeability Transition Pore (MPTP) activity in H9c2 cardiomyocytes were determined by examining MPTP level using Image iT Live Mitochondrial Transition Pore Assay Kit (Molecular Probes) as per manufacturer's instructions. In healthy cells, MPTP is essential for maintaining normal mitochondrial function. In this assay system, cells are loaded with the acetoxymethyl ester of calcein dye, calcein AM which passively diffuses into the cells and accumulates in cytosolic compartments, including mitochondria. Intracellular esterases cleave acetoxymethyl esters to generate highly polar fluorescent dye calcein which does not cross mitochondrial or plasma membranes. In the presence of $\mathrm{CoCl}_{2}$, fluorescence from mitochondrial calcein is maintained whereas fluorescence from cytosolic calcein is quenched. For live cell imaging, cells were cultured in 35mm glass bottom dishes (MatTek, Ashland, MA, USA). The H9c2 cardiomyocytes were pretreated with or without $10 \mu \mathrm{M}$ fenofibrate and incubated in the presence of 100 $\mu \mathrm{M}$ PE for 24 hours. After washing in the modified HBSS buffer, cells were stained by labelling solution containing calcein AM, MitoTracker Red CMXRos, Hoechst 33342 and $\mathrm{CoCl}_{2}$ for 20 minutes. Cells were again washed and observed under confocal microscope. 


\section{Cellular Physiology Cell Physiol Biochem 2018;49:245-259 \begin{tabular}{ll|l} 
and Biochemistry Published online: 23 August, 2018 & $\begin{array}{l}\text { (c) } 2018 \text { The Author(s). Published by S. Karger AG, Basel } \\
\text { www.karger.com/cpb }\end{array}$
\end{tabular}

\section{Statistical Analysis}

The data are presented as mean \pm S.E.M. P value was shown in those experiments where the experiments were repeated at least thrice. Data between two groups were evaluated by Student's t-test (independent) and the complete data set among all treatment groups (three or more, as indicated) was evaluated by oneway ANOVA using Microcal origin 6.0 (Microcal software, Inc., MA, USA). Post hoc analysis was conducted for testing statistical significance among different groups. A level of $\mathrm{P}<0.05$ was set as the threshold for statistical significance between the control and various experimental groups. Resuluts

\section{Results}

\section{Involvement of PPAR $\alpha$ signaling in hypertrophy of cardiomyocytes}

To examine the involvement of PPAR $\alpha$ signaling in hypertrophic growth, H9c2 cardiomyocytes were co-treated with $\alpha_{1}$-adrenergic agonist PE and fenofibrate and various parameters like size, volume of the cells and expression of the marker genes were monitored. Fenofibrate prevented PE induced-increase in ANP, BNP and $\beta$-MHC (Fig. 1A). Actin staining by fluorescent phalloidin revealed increase in cellular surface area in PE-induced cardiomyocytes compared to control which was prevented when co-treated with fenofibrate (Fig. 1B). To visualize the physical increase in size and volume, H9c2 cardiomyocytes were imaged by atomic force microscope (AFM). Spatial increase in cell surface was prominent due to PE treatment which did not happen in the presence of fenofibrate (Fig. 1C). Similarly, actin staining by fluorescent phalloidin revealed increase in cellular surface area in PEinduced NRVM compared to control which was prevented when co-treated with fenofibrate (Fig. 1D). These results indicated that PPAR $\alpha$ is critically involved in phenylephrine-induced hypertrophic signaling pathway in cardiomyocytes.

Downregulation of PPAR $\alpha$ and its target genes

Since down regulation of PPAR $\alpha$ signaling is a prerequisite for hypertrophic growth, we investigated the expression of PPAR $\alpha$ and some of its target genes involved in fatty acid $\beta$-oxidation pathway like CPT-I and MCAD. CPT-I is involved in transesterification activity of fatty acid $\beta$-oxidation. MCAD is the first catalyzer of the fatty acid $\beta$-oxidation pathway. It was observed that mRNA levels of PPAR $\alpha$ and its target genes like CPT-I and MCAD were reduced in PE-treated H9c2 cells. Fenofibrate could

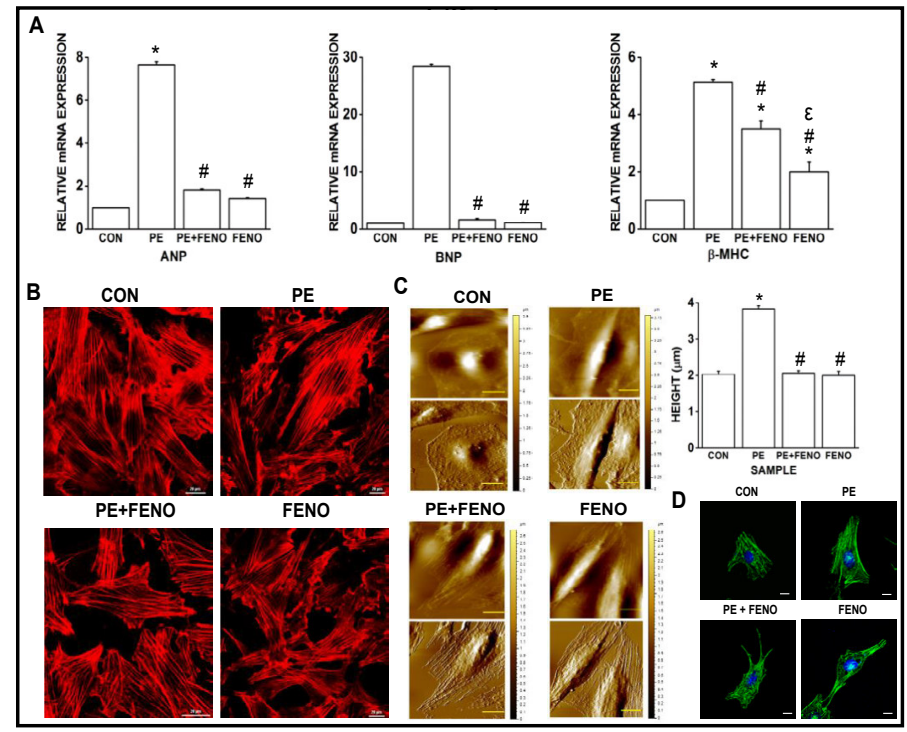

Fig. 1. Involvement of PPAR $\alpha$ signaling in phenylephrine-induced hypertrophy of cardiomyocytes. H9c2 cells were treated either with PE or fenofibrate (FENO) or PE in combination with fenofibrate (PE+FENO). (A) Histograms showing mRNA expression of ANP, $\mathrm{BNP}$ and $\beta$-MHC by quantitative real time PCR. These data represent mean \pm S.E.M of 3 independent experiments. ${ }^{*} \mathrm{p}<0.05$ vs $\mathrm{CON}$, ${ }^{\#} \mathrm{p}<0.05$ vs $\mathrm{PE},{ }^{\varepsilon} \mathrm{p}<0.05$ vs PE+FENO. (B) Representative images of phalloidin stained H9c2 cells after 24 hours of experiment. Scale bar $20 \mu \mathrm{m}$. (C) Representative images of H9c2 cells by atomic force microscopy (AFM). Scale bar: $20 \mu \mathrm{m}$. Each bar represents mean \pm S.E.M of height of 3 cardiomyocytes from different experiments. ${ }^{*} \mathrm{p}<0.001$ vs CON, $\mathrm{p}<0.001$ vs PE. (D) Representative images of phalloidin stained NRVMs after 24 hours of treatments as indicated. 
partially restore PPAR $\alpha$ and MCAD gene expression. However, level of CPT-I was completely normalized as shown in Fig. 2.

\section{Deterioration of mitochondrial dynamics in cardiomyocytes \\ Mitochondrial dynamics and} network organization at the single cell level were monitored by JC-I staining and mitotracker red staining. The network organization was further validated by immunostaining of the fixed cells using COX-I. Stimulation of H9c2 cardiomyocytes with PE compromised mitochondrial dynamics as revealed by significant drop in red/green ratio of JC-I dye (Fig. 3A). Mitochondrial reticulate network and dynamics were observed in control H9c2 cardiomyocytes which were disorganized by PE as revealed by live cell imaging with mitotracker red stain (Fig. 3B, Supplementary Movies 1-4) and also by fixed cell immunostaining of COX-I

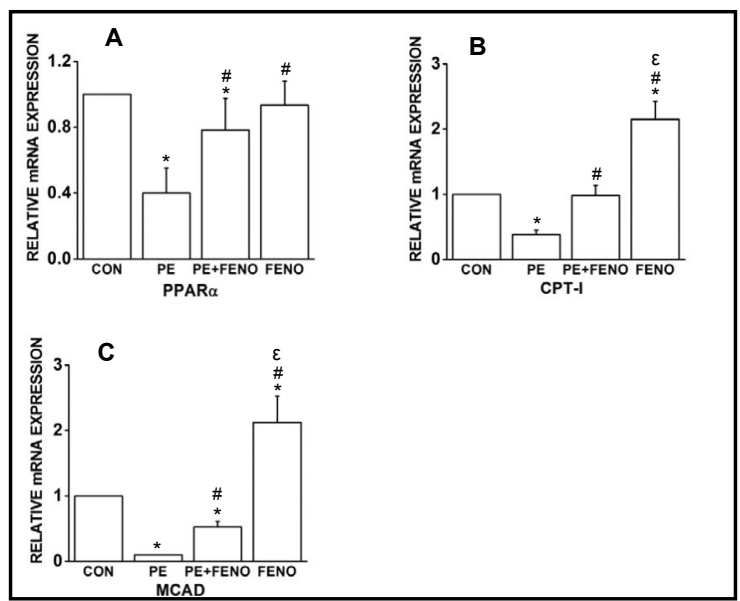

Fig. 2. Down regulation of PPAR $\alpha$ and its target genes. Histograms showing mRNA expression of PPAR $\alpha(A)$, CPT-I (B) and MCAD (C) in cells treated as above by quantitative real time PCR. These data represent mean \pm S.E.M of 3 independent experiments. (A) ${ }^{*} \mathrm{p}<0.05$ vs CON, ${ }^{\#}$ p $<0.05$ vs PE, (B\&C) * $\mathrm{p}<0.001$ vs CON, ${ }^{*} \mathrm{p}<0.05$ vs $P E,{ }^{\varepsilon} \mathrm{p}<0.05$ vs PE+FENO.

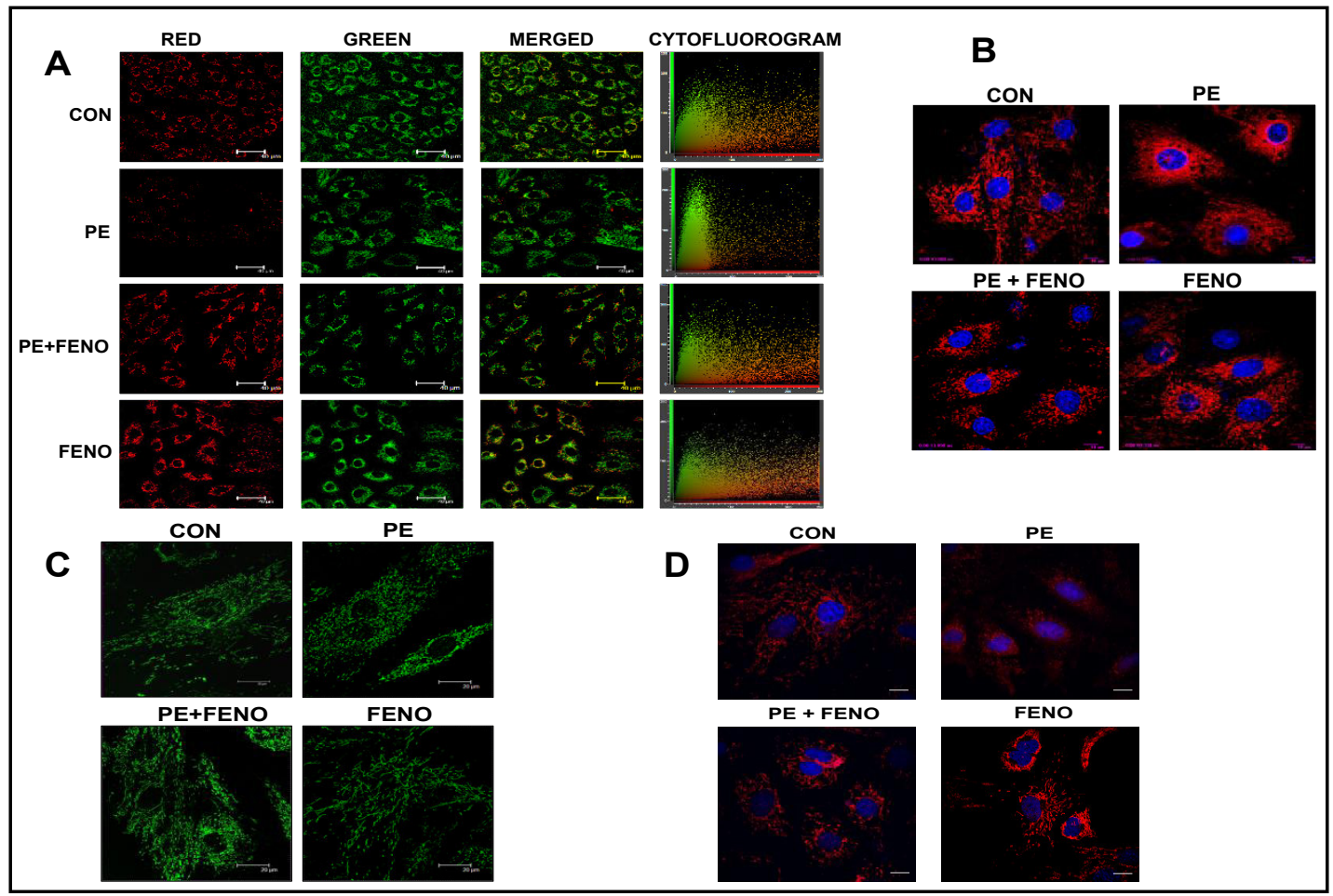

Fig. 3. Abrogation of trans-membrane potential, mitochondrial dynamics and network organization in cardiomyocytes by PE. (A) Confocal micrograph showing JC-I staining pattern of H9c2 cardiomyocytes after different treatment conditions. Scale bar: $40 \mu \mathrm{m}$. (B) Mitochondrial dynamics in H9c2 cardiomyocytes by live cell imaging using mitotracker red stain. Scale bar: $10 \mu \mathrm{m}$. (C) Confocal micrograph of fixed H9c2 cardiomyocytes immunostained for COX-I after different treatment conditions. Scale bar: $20 \mu \mathrm{m}$. (D) Mitochondrial dynamics in NRVM by live cell imaging using mitotracker red stain. Scale bar: $10 \mu \mathrm{m}$. 


\section{Cellular Physiology Cell Physiol Biochem 2018;49:245-259

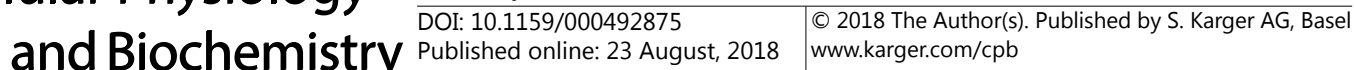

(Fig. 3C). For all supplemental material see www.karger. com/10.1159/000492875. Similarly, mitochondrial reticulate network was compromised by PE in NRVMs as demonstrated by live cell imaging with mitotracker red stain (Fig. 3D). Mitochondrial dynamics and network organization were found to be partially restored when cardiac cells were co-treated with PPAR $\alpha$ agonist fenofibrate (Supplementary Movie 3). Timelapse imaging of mitochondrial dynamics (Supplementary Movies 1-4) displayed reduced mitochondrial connectivity and motility due to PE treatment which was partially restored when cardiac cells were cotreated with PPAR $\alpha$ agonist fenofibrate.

Bezafibrate prevents

phenylephrine-induced hypertrophic response and
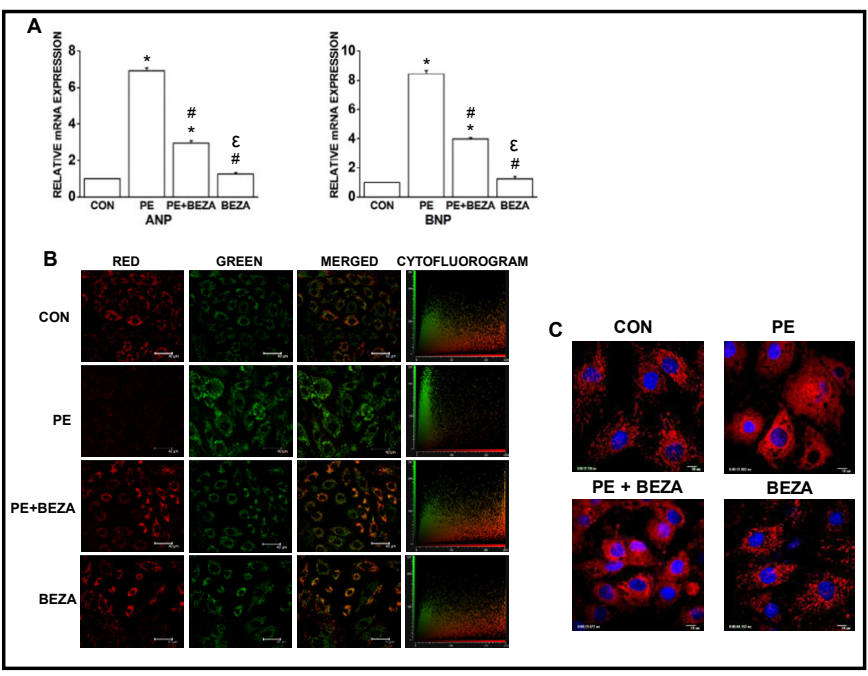

Fig. 4. Bezafibrate prevents phenylephrine-induced hypertrophic condition and mitochondrial dysfunction in H9c2 cells. H9c2 cells were treated either with PE or bezafibrate (BEZA) or PE in combination with bezafibrate (PE+BEZA). (A) Histograms showing mRNA expression of ANP and BNP by quantitative real time PCR. These data represent mean \pm S.E.M of 3 independent experiments. ${ }^{*} \mathrm{p}<0.05$ vs $\mathrm{CON},{ }^{\sharp} \mathrm{p}<0.05$ vs $\mathrm{PE},{ }^{\varepsilon} \mathrm{p}<0.05$ vs PE+BEZA. (B) Confocal micrograph showing JC-I staining pattern of H9c2 cardiomyocytes after different treatment conditions. Scale bar: $40 \mu \mathrm{m}$. (C) Mitochondrial dynamics in H9c2 cardiomyocytes by live cell imaging using mitotracker red stain. Scale bar: $10 \mu \mathrm{m}$.

mitochondrial dysfunction

Another PPAR $\alpha$ agonist, bezafibrate, which may have some activity on PPAR $\beta / \delta$ also prevented PE induced-increase in ANP and BNP (Fig. 4A). Furthermore, PE-induced deterioration of mitochondrial dynamics and network organization in hypertrophic cardiomyocytes were partially restored in presence of bezafibrate (Fig. 4B \& 4C) (Supplementary Movies 5-8). It also partially restored mitochondrial connectivity and motility affected by PE as shown in time-lapse imaging (Supplementary Movies 5-8).

\section{Oxidative stress in hypertrophic condition}

To assess oxidative stress status both mitochondrial and cellular reactive oxygen species (ROS) were examined in H9c2 cardiomyocytes in the absence or presence of fenofibrate along with PE. As shown in Fig. 5A and 5B, cellular and mitochondrial ROS were significantly increased in PE-induced hypertrophic cardiomyocytes. It was not significantly altered when co-stimulated with fenofibrate. It is important to note that fenofibrate alone did not affect mitochondrial and cellular ROS production compared to control cardiomyocytes.

\section{Calcium homeostasis}

Since calcium level is important for maintaining proper cellular and mitochondrial machinery we measured both mitochondrial and cellular calcium level. As shown in Fig. 6A and $6 \mathrm{~B}$ both cellular and mitochondrial calcium were significantly increased in PE-induced hypertrophic cardiomyocytes. But fenofibrate could significantly prevent the increase in both mitochondrial and cellular calcium level in PE-induced hypertrophic cardiomyocytes.

\section{Effect of Fenofibrate in mitochondrial activity}

Mitochondrial activity was measured by observing mitochondrial permeability transition pore (MPTP) activity by live cell imaging (Fig. 7A), total ATP concentration (Fig. 7B) 
Fig. 5. Fenofibrate prevents oxidative damage in hypertrophic cardiomyocytes. H9c2 cardiomyocytes were treated either with PE or FENO or PE in combination with FENO (PE+FENO). Confocal micrograph showing cellular (A) and mitochondrial (B) reactive oxygen species (ROS). Scale bar: $20 \mu \mathrm{m}$. These data represent mean \pm S.E.M of 3 independent experiments. ${ }^{*} \mathrm{p}<0.001$ vs $\mathrm{CON},{ }^{\#} \mathrm{p}<0.001$ vs $\mathrm{PE},{ }^{\varepsilon} \mathrm{p}<0.001$ vs PE+FENO.

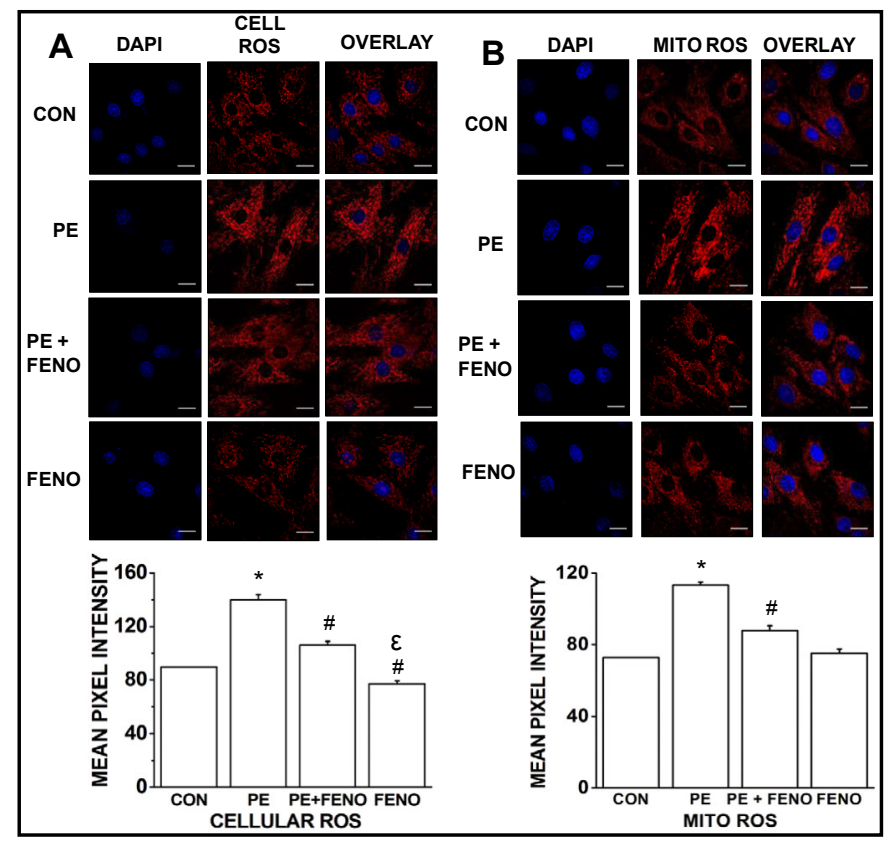

Fig. 6. Fenofibrate prevents loss in calcium homeostasis in hypertrophic cardiomyocytes. Confocal micrograph showing $\mathrm{Ca}^{2+}$ level in cytosol (A) and as mitochondria (B) in $\mathrm{H} 9 \mathrm{c} 2$ cardiomyocytes after $24 \mathrm{~h}$ of treatment as described above. Scale bar: $20 \mu \mathrm{m}$. These data represent mean \pm S.E.M of 3 independent experiments. (A) ${ }^{*} \mathrm{p}<0.001$ vs CON, ${ }^{*} \mathrm{p}<0.05$ vs PE. (B) ${ }^{*} \mathrm{p}<0.001$ vs CON, ${ }^{\#} \mathrm{p}<0.001$ vs PE.

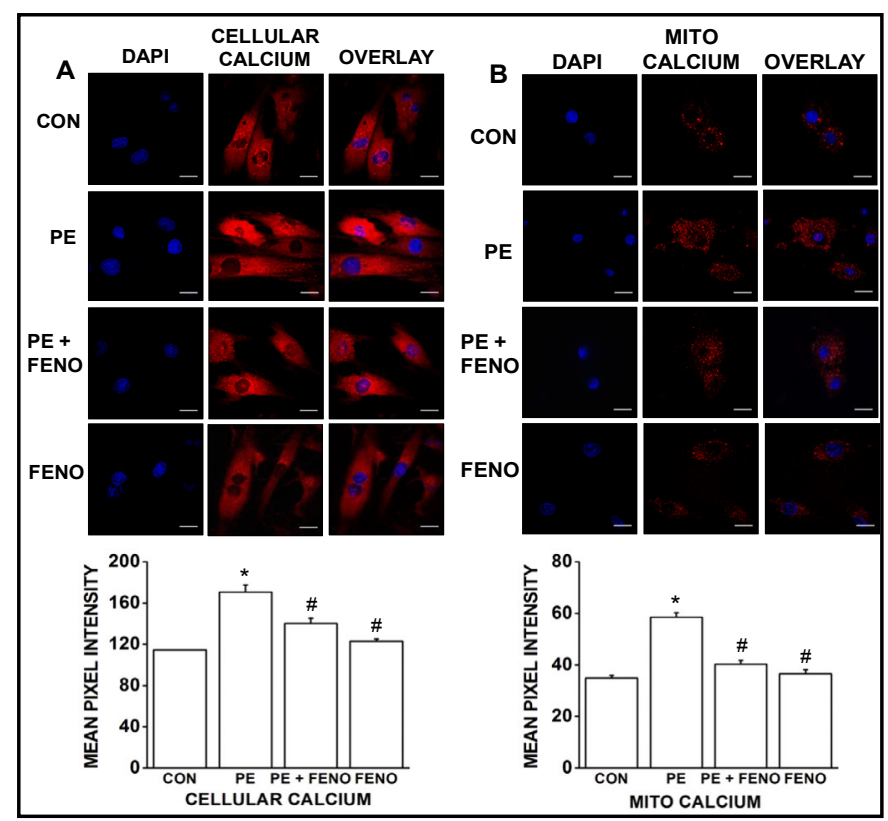

and mitochondrial complex V (ATP Synthase) activity (Fig. 7C). It was found that significant drop in MPTP activity, total ATP concentration and mitochondrial complex V activity in PEtreated hypertrophic condition was significantly restored when $\mathrm{H} 9 \mathrm{c} 2$ cardiomyocytes were co-treated with fenofibrate along with PE.

\section{Fenofibrate mediated restoration of mitochondrial genes}

To examine whether mitochondrial dysfunction was due to altered expression of any critical component of mitochondria in hypertrophied condition, expression of VDAC and COXIV were monitored in H9c2 cardiomyocytes following treatment with PE in the absence or presence of fenofibrate. Although PE caused decreased level of VDAC mRNA, level of COX-IV was increased. Fenofibrate partially restored PE-induced decrease in VDAC mRNA level whereas 
PE-induced increase in COX-IV mRNA level remains unaltered (Fig. 8A). To understand the mechanism of down regulation of VDAC mRNA computational analysis was performed to check whether VDAC has any known or predictive miRNA regulators. Target Scan analysis revealed few miRNAs as putative regulators of VDAC as shown in Fig. 8B.

\section{Regulation of miRNAs by fenofibrate}

The miRNAs which were found to be putative regulators of VDAC were altered by PE in cardiomyocytes and fenofibrate were able to partially restore them (Fig. 9) indicating involvement of PPAR $\alpha$ pathway.

\section{VDAC-miRNA interaction studies}

To understand whether VDAC is indeed interacting with miR28 we performed luciferase interaction studies. After $48 \mathrm{~h}$ of transfection with $20 \mathrm{nM}$ of miR28 mimic a very high mRNA level of miR28 was observed (Fig. 10A). VDAC mRNA level was found to be significantly downregulated in $\mathrm{H} 9 \mathrm{c} 2$ cardiomyocytes after $48 \mathrm{~h}$ of miR28 mimic transfection providing indirect evidence regarding VDACmiR28 interaction (Fig. 10B). To investigate further whether miR28 directly interacts with VDAC, 3' UTR of VDAC and miR28 mimic were co-transfected into the cardiomyocytes for $72 \mathrm{~h}$ and luciferase signal was monitored. Significant drop in luciferase signal confirmed that VDAC 3' UTR binds to miR28 seed sequence (Fig. 10C). Discussion

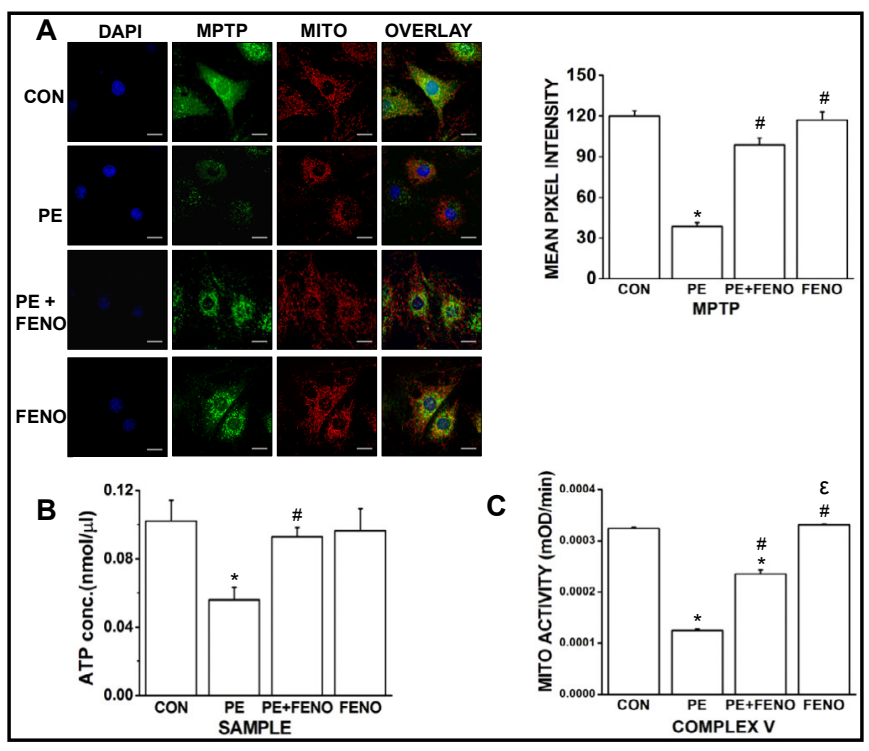

Fig. 7. Fenofibrate prevents loss in mitochondrial activity in hypertrophic cardiomyocytes. (A) Representative confocal micrograph of H9c2 cardiomyocytes stained with calcein AM and mitotracker red CMXRos after different treatment conditions as indicated. Scale bar: $20 \mu \mathrm{m}$. Right panel represents mean \pm S.E.M of pixel intensity of the cardiomyocytes stained with calcein $(\mathrm{n}=3) .{ }^{*} \mathrm{p}<0.001$ vs CON, ${ }^{*} \mathrm{p}<0.001$ vs PE. (B) Histogram showing total ATP concentration $(\mathrm{nmol} / \mu \mathrm{l})$ in $\mathrm{H} 9 \mathrm{c} 2$ cardiomyocytes after different treatment conditions. ${ }^{*} \mathrm{p}<0.05$ vs $\mathrm{CON},{ }^{*} \mathrm{p}<0.05$ vs PE. (C) Mitochondrial complex V (ATP synthase) activity (mOD/min) in $\mathrm{H} 9 \mathrm{c} 2$ cardiomyocytes. These data represent mean \pm S.E.M of 3 independent experiments. $\quad{ }^{*} \mathrm{p}<0.001$ vs $\mathrm{CON},{ }^{*} \mathrm{p}<0.001$ vs $\mathrm{PE}$, ${ }^{\varepsilon} \mathrm{p}<0.001$ vs $\mathrm{PE}+\mathrm{FENO}$.

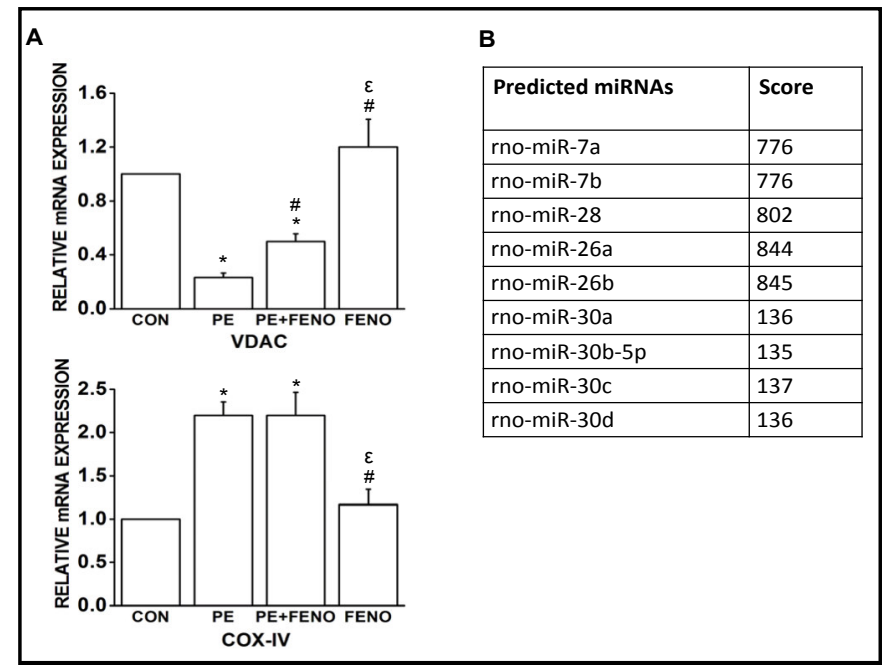

Fig. 8. Alteration of mitochondrial genes in cardiac hypertrophic condition. (A) Histograms showing mRNA expression of VDAC and COX-IV by quantitative real time PCR. ${ }^{*} \mathrm{p}<0.05$ vs CON, ${ }^{\#} \mathrm{p}<0.05$ vs $\mathrm{PE},{ }^{\varepsilon} \mathrm{p}<0.05$ vs PE+FENO. (B) Bioinformatic analysis using Targetscan software showing a list of putative microRNAs for VDAC. 


\section{Cellular Physiology Cell Physiol Biochem 2018;49:245-259 \begin{tabular}{l|l|l} 
and Biochemistry & DOI: 10.1159/000492875 & $\begin{array}{l}\text { (c) } 2018 \text { The Author(s). Published by S. Karger AG, Basel } \\
\text { www.kargercom/cpb }\end{array}$
\end{tabular}

\section{Discussion}

The cardiomyocytes have unique ability to deal with various kinds of stress by structural and biochemical remodeling which renders considerable physiological flexibility to the myocardium. However, chronic stress to the myocytes lead to malfunction of the intracellular machineries in which mitochondria is mostly affected. This study reveals a mechanistic significance of PPAR $\alpha$ signaling which is one of the ways leading to mitochondrial dysfunction in hypertrophied cardiomyocytes. We further demonstrate that miR 28 mediated down regulation of VDAC, a key structural component of the organelle might be an important cause of mitochondrial abnormalities.

Earlier studies showed that in rat heartderived embryonic H9c2 cardiomyoblastic cells PPAR $\beta / \delta$ and PPAR $\alpha$ subtypes are found [33-35]. Down regulation of PPAR $\alpha$ in cardiomyocytes is common to many types of hypertrophic stimuli [26, 36-39]. Consistent with earlier reports we have validated its causal relationship with the hypertrophic process by using its agonists, fenofibrate (Fig. 1 and 2) and bezafibrate (Fig. 4). PPAR $\alpha$ regulates key genes involved in $\beta$-oxidation cycle by binding to response elements present in the promoter region of the corresponding target genes like carnitine palmitoyl transferase-I ( CPT-I), medium chain acyl dehydrogenase (MCAD) etc. CPT-I regulates the first limiting step in mitochondrial fatty acid $\beta$-oxidation i.e. the entry flux of fatty acids into mitochondria by catalyzing formation of fatty acyl carnitine for its translocation across inner mitochondrial membrane. MCAD, another crucial gene in mitochondrial fatty acid $\beta$-oxidation, catalyzes the initial reaction in this pathway [20, 40-43]. It is apparent that reduced expression of these genes in PE-induced hypertrophied cardiomyocytes results into mitochondrial abnormality. Cellular stress by PE affects both structural as well as functional state of mitochondria. Mitochondrial trans-membrane potential $\left(\Delta \psi_{\mathrm{m}}\right)$ is found to be compromised by PE which is associated with oxidative stress, diminution of intracellular $\mathrm{Ca}^{2+}$, decrease in mitochondrial activity, depletion of ATP and altered mitochondrial bioenergetics (Fig. 3

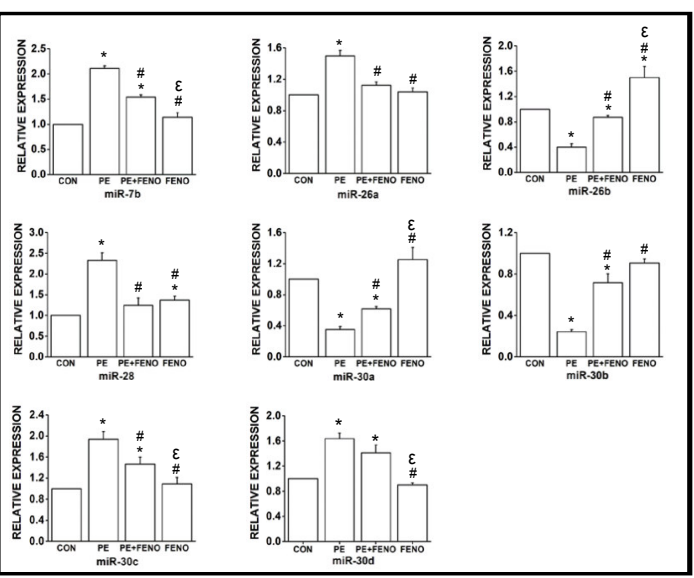

Fig. 9. Effect of fenofibrate on miRNAs altered by phenylephrine in cardiomyocytes. Histograms showing expression of all the enlisted miRNAs revealed by bioinformatic analysis which could putatively bind to VDAC by quantitative real time PCR. ${ }^{*} \mathrm{p}<0.05$ vs CON, ${ }^{*} \mathrm{p}<0.05$ vs $\mathrm{PE},{ }^{\varepsilon} \mathrm{p}<0.05$ vs PE+FENO.

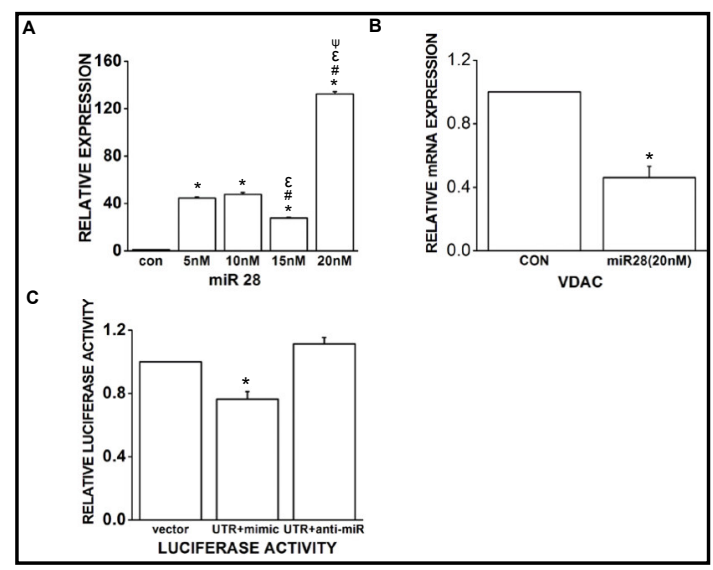

Fig. 10. Regulation of VDAC by miR28. (A) Histograms showing expression of miR28 in cells transfected with miR28 mimic by quantitative real time PCR. These data represent mean \pm S.E.M of 3 independent experiments. ${ }^{*} \mathrm{p}<0.001$ vs con, ${ }^{*} \mathrm{p}<0.001$ vs miR28 (5nM), ${ }^{\varepsilon} \mathrm{p}<0.001$ vs miR28 (10nM), ${ }^{4} \mathrm{p}<0.001$ vs miR28 (15nM). (B) Histograms showing expression of VDAC mRNA in cells transfected with miR28 mimic for $48 \mathrm{~h}$ by quantitative real time PCR. These data represent mean \pm S.E.M of 3 independent experiments. ${ }^{*} \mathrm{p}<0.005$ (C) Luciferase activity in H9c2 cardiomyocytes which were either transfected with blank luciferase vector or co-transfected with luciferase reporter plasmid containing 3' UTR of VDAC along with either miR28 mimic or anti-miR28 for 96 hours. ${ }^{*} \mathrm{p}<0.05$ vs UTR+mimic. 


\section{\begin{tabular}{ll} 
Cellular Physiology & Cell Physiol Biochem 2018;49:245-259 \\
\hline DOI: 10.1159/000492875 & O 2018 The Author(s). Published by S. Karger AG, Basel
\end{tabular}

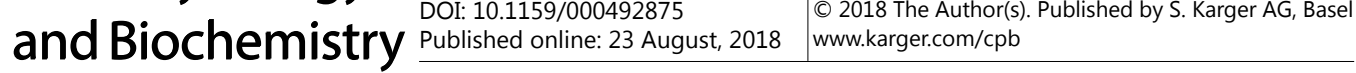 \\ Kar et al.: Role of PPAR $\alpha$ in Prevention of Cardiomyocyte Hypertrophy}

and Fig. 5-7). In overall, we have shown that fenofibrate prevents adverse effects of PE in cardiomyocytes including cellular hypertrophy and impaired mitochondrial function.

Healthy mitochondria in cardiomyocytes are characterized by prominent reticulate network and dynamic nature $[44,45]$. Previously, we have shown that such reticulate network is gradually disrupted with the duration of PE-treatment leading to loss of mitochondrial dynamicity [21]. Consequently, mitochondrial ROS is generated leading to a cascading effect to its physiology. Gradual decline in bioenergetic reserve capacity may ultimately cause decompensation and faulty energy supply leading to heart failure [46, 47].

Recent reports indicate that MPTP regulates calcium efflux and influx thereby maintaining normal mitochondrial function $[6,48]$. Fenofibrate prevents impairment of MPTP and restored PE-induced drop in cellular and mitochondrial calcium in the present study (Fig. 6).

The outer mitochondrial membrane protein VDAC is an integral part of MPTP complex. It regulates transport of small solutes upto $1.5 \mathrm{kDa}$ in size, import of ADP in exchange of ATP thereby maintaining ATP homeostasis inside cell, transfer of calcium ions across mitochondrial outer membrane for the maintenance of calcium homeostasis $[6,48,49]$. Hence decreased activity of VDAC might lead to diminished mitochondrial activity which results in increased oxidative stress, calcium ion imbalance, loss of mitochondrial membrane potential leading to mitochondrial dysfunction. For understanding the mechanism of down regulation of VDAC, computational analysis was performed to find out putative miRNAs which could bind to its untranslated region (UTR) (Fig. 8B). Since each of these miRNAs can theoretically bind to VDAC as predicted by computational analysis we found alteration of all the predicted miRNAs in phenylephrine-induced hypertrophic condition via PPAR $\alpha$ pathway (Fig. 9). Accordingly, miR28 is found to be one of the potential candidates specifically regulated by PPAR $\alpha$ signaling. It is an intragenic microRNA and has been found to be altered in several cancers. It has also been found to be involved in apoptosis and cell cycle control [50]. Here we show the involvement of miR28 regulating expression of a mitochondrial protein in cardiomyocytes. Involvement of other miRNAs in regulating VDAC cannot be ruled out. Thus, miR28 plays a significant role in maintaining MPTP complex via regulating VDAC expression which might be one possible mechanism by which nuclear-mitochondrial cross talk operates in cardiomyocytes (Fig. 11).

In conclusion, the present study unveiled the mechanistic significance of PPAR $\alpha$ signaling in cardiomyocytes, deregulation of which leads to mitochondrial abnormalities in hypertrophy. We have already shown that for the development of LV hypertrophy dysregulation of PPAR $\alpha$ mediated signaling pathway is crucial and PPAR $\alpha$ is also critical for maintaining myocardial mitochondrial integrity in vivo [20]. These findings have a larger implication since PPAR $\alpha$ is an important drug target for the management of deranged lipid profile in human. As most of the phenotypes of defunct mitochondria and the hypertrophy of the cardiomyocytes are

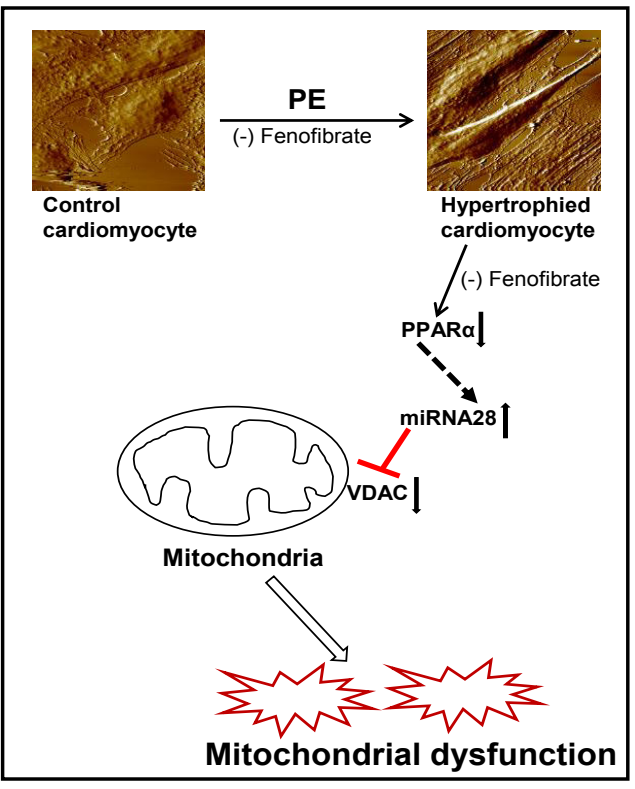

Fig. 11. Schematic representation depicting a possible mechanism of mitochondrial dysfunctions in cardiomyocytes. Treatment of the cardiomyocytes by PE induces increase in size accompanied with molecular changes including upregulation of miR28 which is responsible for down regulation of mitochondrial outer membrane protein VDAC. Consequently, molecular alteration leads to overall dysfunction of mitochondria. The occurrence of PE induced hypertrophy and altered biochemical and molecular events leading to mitochondrial disorders are critically regulated via PPAR $\alpha$ pathway. 


\section{Cellular Physiology Cell Physiol Biochem 2018;49:245-259 \begin{tabular}{l|l|l} 
and Biochemistry Published online: 23 August, 2018 & $\begin{array}{l}\text { @ } 2018 \text { The Author(s). Published by S. Karger AG, Basel } \\
\text { www.karger.com/cpb }\end{array}$ \\
\hline
\end{tabular}}

significantly reversed by fenofibrate, it is likely that PPAR $\alpha$ agonist holds great promise for cardio protection in addition to its well established lipid-lowering effect. A gradual decline in bioenergetic reserve capacity may ultimately cause decompensation and faulty energy supply leading to heart failure.

\section{Acknowledgements}

We thank Dr. Beena Pillai, CSIR-IGIB, New Delhi for providing with VDAC luciferase plasmids. AB gratefully acknowledges the Atomic Force Microscopy Facility at CSIR-IICB and Live Cell Imaging Facility co-funded by the Wellcome Trust and CSIR for the imaging experiments. Arun Bandyopadhyay and Dipak Kar conceived and designed the experiments. Dipak Kar carried out the experiments. Dipak Kar and Arun Bandyopadhyay analyzed the data and wrote the manuscript. This work is supported by grants from Council of Scientific and Industrial Research (CSIR), New Delhi, India (grant \# BSC 0206). Dipak Kar is a recipient of Senior Research Fellowship from CSIR, New Delhi.

\section{Disclosure Statement}

The authors declare that no potential conflicts of interest exists.

\section{References}

$>1$ Heineke J, Molkentin JD: Regulation of cardiac hypertrophy by intracellular signalling pathways. Nat Rev Mol Cell Biol 2006;7:589-600.

-2 Heineke J, Auger-Messier M, Correll RN, Xu J, Benard MJ, Yuan W, Drexler H, Parise LV, Molkentin JD: CIB1 is a regulator of pathological cardiac hypertrophy. Nat Med 2010;16:872-879.

-3 McMullen JR, Jennings GL: Differences between pathological and physiological cardiac hypertrophy: novel therapeutic strategies to treat heart failure. Clin Exp Pharmacol Physiol 2007;34:255-262.

-4 Hansson A, Hance N, Dufour E, Rantanen A, Hultenby K, Clayton DA, Wibom R, Larsson NG: A switch in metabolism precedes increased mitochondrial biogenesis in respiratory chain-deficient mouse hearts. Proc Natl Acad Sci U S A 2004;101:3136-3141.

$>5$ Kuzmicic J, Del Campo A, Lopez-Crisosto C, Morales PE, Pennanen C, Bravo-Sagua R, Hechenleitner J, Zepeda R, Castro PF, Verdejo HE, Parra V, Chiong M, Lavandero S: Mitochondrial dynamics: a potential new therapeutic target for heart failure. Rev Esp Cardiol 2011;64:916-923.

6 Pennanen C, Parra V, Lopez-Crisosto C, Morales PE, Del Campo A, Gutierrez T, Rivera-Mejias P, Kuzmicic J, Chiong M, Zorzano A, Rothermel BA, Lavandero S: Mitochondrial fission is required for cardiomyocyte hypertrophy mediated by a Ca2+-calcineurin signaling pathway. J Cell Sci 2014;127:2659-2671.

7 Sack MN, Disch DL, Rockman HA, Kelly DP: A role for Sp and nuclear receptor transcription factors in a cardiac hypertrophic growth program. Proc Natl Acad Sci U S A 1997;94:6438-6443.

-8 Palaniyandi SS, Qi X, Yogalingam G, Ferreira JC, Mochly-Rosen D: Regulation of mitochondrial processes: a target for heart failure. Drug Discov Today Dis Mech 2010;7:e95-e102.

-9 Huss JM, Kelly DP: Nuclear receptor signaling and cardiac energetics. Circ Res 2004;95:568-578.

10 Nagoshi T, Yoshimura M, Rosano GM, Lopaschuk GD, Mochizuki S: Optimization of cardiac metabolism in heart failure. Curr Pharm Des 2011;17:3846-3853.

11 Ventura-Clapier R, Garnier A, Veksler V: Energy metabolism in heart failure. J Physiol 2004;555:1-13.

12 Camara AK, Bienengraeber M, Stowe DF: Mitochondrial approaches to protect against cardiac ischemia and reperfusion injury. Front Physiol 2011;2:13.

13 Ong SB, Hall AR, Hausenloy DJ: Mitochondrial dynamics in cardiovascular health and disease. Antioxid Redox Signal 2013;19:400-414.

14 Evans RM, Barish GD, Wang YX: PPARs and the complex journey to obesity. Nat Med 2004;10:355-361. 


\section{Cellular Physiology Cell Physiol Biochem 2018;49:245-259 \begin{tabular}{l|l|l} 
and Biochemistry & DOI: 10.1159/000492875 & $\begin{array}{l}\text { (c) } 2018 \text { The Author(s). Published by S. Karger AG, Basel } \\
\text { www.karger.com/cpb }\end{array}$
\end{tabular}

15 Huang Y, Zhang H, Shao Z, O'Hara KA, Kopilas MA, Yu L, Netticadan T, Anderson HD: Suppression of endothelin-1-induced cardiac myocyte hypertrophy by PPAR agonists: role of diacylglycerol kinase zeta. Cardiovasc Res 2011;90:267-275.

16 Rowe GC, Jiang A, Arany Z: PGC-1 coactivators in cardiac development and disease. Circ Res 2010;107:825838.

17 Hamblin M, Chang L, Fan Y, Zhang J, Chen YE: PPARs and the cardiovascular system. Antioxid Redox Signal 2009;11:1415-1452.

18 Wang YX: PPARs: diverse regulators in energy metabolism and metabolic diseases. Cell Res 2010;20:124137.

19 Oka S, Alcendor R, Zhai P, Park JY, Shao D, Cho J, Yamamoto T, Tian B, Sadoshima J: PPARalpha-Sirt1 complex mediates cardiac hypertrophy and failure through suppression of the ERR transcriptional pathway. Cell Metab 2011;14:598-611.

20 Maity S, Kar D, De K, Chander V, Bandyopadhyay A: Hyperthyroidism causes cardiac dysfunction by mitochondrial impairment and energy depletion. J Endocrinol 2013;217:215-228.

-21 Banerjee P, Chander V, Bandyopadhyay A: Balancing functions of annexin A6 maintain equilibrium between hypertrophy and apoptosis in cardiomyocytes. Cell Death Dis 2015;6:e1873.

22 Zhang H, Li S, Zhou Q, Sun Q Shen S, Zhou Y, Bei Y, Li X: Qiliqiangxin Attenuates Phenylephrine-Induced Cardiac Hypertrophy through Downregulation of MiR-199a-5p. Cell Physiol Biochem 2016;38:1743-1751.

-23 Wang YS, Zhou J, Hong K, Cheng XS, Li YG: MicroRNA-223 displays a protective role against cardiomyocyte hypertrophy by targeting cardiac troponin I-interacting kinase. Cell Physiol Biochem 2015;35:1546-1556.

24 He L, Hannon GJ: MicroRNAs: small RNAs with a big role in gene regulation. Nat Rev Genet 2004;5:522531.

25 Banerjee P, Bandyopadhyay A: Cytosolic dynamics of annexin A6 trigger feedback regulation of hypertrophy via atrial natriuretic peptide in cardiomyocytes. J Biol Chem 2014;289:5371-5385.

-26 Barger PM, Brandt JM, Leone TC, Weinheimer CJ, Kelly DP: Deactivation of peroxisome proliferatoractivated receptor-alpha during cardiac hypertrophic growth. J Clin Invest 2000;105:1723-1730.

27 Shen P, Feng X, Zhang X, Huang X, Liu S, Lu X, Li J, You J, Lu J, Li Z, Ye J, Liu P: SIRT6 suppresses phenylephrine-induced cardiomyocyte hypertrophy though inhibiting p300. J Pharmacol Sci 2016;132:3140.

28 De Silva DS, Wilson RM, Hutchinson C, Ip PC, Garcia AG, Lancel S, Ito M, Pimentel DR, Sam F: Fenofibrate inhibits aldosterone-induced apoptosis in adult rat ventricular myocytes via stress-activated kinasedependent mechanisms. Am J Physiol Heart Circ Physiol 2009;296:H1983-1993.

29 Irukayama-Tomobe Y, Miyauchi T, Kasuya Y, Sakai S, Goto K, Yamaguchi I: Activation of peroxisome proliferator-activated receptor-alpha decreases endothelin-1-induced p38 mitogen-activated protein kinase activation in cardiomyocytes. J Cardiovasc Pharmacol 2004;44 Suppl 1:S358-361.

-30 Bandyopadhyay A, Shin DW, Ahn JO, Kim DH: Calcineurin regulates ryanodine receptor/Ca(2+)-release channels in rat heart. Biochem J 2000;352 Pt 1:61-70.

-31 Gomez JP, Potreau D, Raymond G: Intracellular calcium transients from newborn rat cardiomyocytes in primary culture. Cell Calcium 1994;15:265-275.

-32 Livak KJ, Schmittgen TD: Analysis of relative gene expression data using real-time quantitative PCR and the 2(-Delta Delta C(T)) Method. Methods 2001;25:402-408.

-33 Pesant M, Sueur S, Dutartre P, Tallandier M, Grimaldi PA, Rochette L, Connat JL: Peroxisome proliferatoractivated receptor delta (PPARdelta) activation protects H9c2 cardiomyoblasts from oxidative stressinduced apoptosis. Cardiovasc Res 2006;69:440-449.

-34 Jiang YJ, Lu B, Xu FY, Gartshore J, Taylor WA, Halayko AJ, Gonzalez FJ, Takasaki J, Choy PC, Hatch GM: Stimulation of cardiac cardiolipin biosynthesis by PPARalpha activation. J Lipid Res 2004;45:244-252.

-35 Tzeng J, Byun J, Park JY, Yamamoto T, Schesing K, Tian B, Sadoshima J, Oka S: An Ideal PPAR Response Element Bound to and Activated by PPARalpha. PLoS One 2015;10:e0134996.

-36 Li R, Zheng W, Pi R, Gao J, Zhang H, Wang P, Le K, Liu P: Activation of peroxisome proliferator-activated receptor-alpha prevents glycogen synthase 3 beta phosphorylation and inhibits cardiac hypertrophy. FEBS Lett 2007;581:3311-3316.

-37 Duhaney TA, Cui L, Rude MK, Lebrasseur NK, Ngoy S, De Silva DS, Siwik DA, Liao R, Sam F: Peroxisome proliferator-activated receptor alpha-independent actions of fenofibrate exacerbates left ventricular dilation and fibrosis in chronic pressure overload. Hypertension 2007;49:1084-1094. 


\section{Cellular Physiology Cell Physiol Biochem 2018;49:245-259 \begin{tabular}{l|l} 
DOI: 10.1159/000492875 & $\begin{array}{l}\text { O 2018 The Author(s). Published by S. Karger AG, Basel } \\
\text { www.karger.com/cpb }\end{array}$
\end{tabular} \\ Kar et al.: Role of PPAR $\alpha$ in Prevention of Cardiomyocyte Hypertrophy}

-38 Zou J, Le K, Xu S, Chen J, Liu Z, Chao X, Geng B, Luo J, Zeng S, Ye J, Liu P: Fenofibrate ameliorates cardiac hypertrophy by activation of peroxisome proliferator-activated receptor-alpha partly via preventing p65NFkappaB binding to NFATc4. Mol Cell Endocrinol 2013;370:103-112.

-39 Huang Q Huang J, Zeng Z, Luo J, Liu P, Chen S, Liu B, Pan X, Zang L, Zhou S: Effects of ERK1/2/PPARalpha/ SCAD signal pathways on cardiomyocyte hypertrophy induced by insulin-like growth factor 1 and phenylephrine. Life Sci 2015;124:41-49.

40 Gulick T, Cresci S, Caira T, Moore DD, Kelly DP: The peroxisome proliferator-activated receptor regulates mitochondrial fatty acid oxidative enzyme gene expression. Proc Natl Acad Sci U S A 1994;91:1101211016.

-41 Desvergne B, Wahli W: Peroxisome proliferator-activated receptors: nuclear control of metabolism. Endocr Rev 1999;20:649-688.

42 Alaynick WA: Nuclear receptors, mitochondria and lipid metabolism. Mitochondrion 2008;8:329-337.

43 Finck BN: The PPAR regulatory system in cardiac physiology and disease. Cardiovasc Res 2007;73:269277.

44 Piquereau J, Caffin F, Novotova M, Lemaire C, Veksler V, Garnier A, Ventura-Clapier R, Joubert F: Mitochondrial dynamics in the adult cardiomyocytes: which roles for a highly specialized cell? Front Physiol 2013;4:102.

45 Zhou L, O’Rourke B: Cardiac mitochondrial network excitability: insights from computational analysis. Am J Physiol Heart Circ Physiol 2012;302:H2178-2189.

46 Wu F, Zhang J, Beard DA: Experimentally observed phenomena on cardiac energetics in heart failure emerge from simulations of cardiac metabolism. Proc Natl Acad Sci U S A 2009;106:7143-7148.

47 Brown DA, Perry JB, Allen ME, Sabbah HN, Stauffer BL, Shaikh SR, Cleland JG, Colucci WS, Butler J, Voors AA, Anker SD, Pitt B, Pieske B, Filippatos G, Greene SJ, Gheorghiade M: Expert consensus document: Mitochondrial function as a therapeutic target in heart failure. Nat Rev Cardiol 2017;14:238-250.

48 Kwong JQ, Molkentin JD: Physiological and pathological roles of the mitochondrial permeability transition pore in the heart. Cell Metab 2015;21:206-214.

49 Huang H, Hu X, Eno CO, Zhao G, Li C, White C: An interaction between Bcl-xL and the voltage-dependent anion channel (VDAC) promotes mitochondrial Ca2+ uptake. J Biol Chem 2013;288:19870-19881.

50 Schneider C, Setty M, Holmes AB, Maute RL, Leslie CS, Mussolin L, Rosolen A, Dalla-Favera R, Basso K: MicroRNA 28 controls cell proliferation and is down-regulated in B-cell lymphomas. Proc Natl Acad Sci U S A 2014;111:8185-8190. 